\title{
条件付確率場を用いた海洋観測データの品質管理
}

\section{Quality Control of Ocean Observation Data Using Conditional Random Field}

\author{
上川路 洋介＼cjkstart鹿児島大学大学院 理工学研究科 情報生体システム工学専攻 \\ Yosuke Kamikawaji Department of Information Science and Biomedical Engineering,Graduate School of Science and Engineering, Kagoshima University \\ 松山開 \\ （同上） \\ 福井健一 \\ Ken-ichi Fukui \\ 大阪大学 産業科学研究所 \\ The Institute of Scientific and Industrial Research, Osaka University \\ fukui@ai.sanken.osaka-u.ac.jp \\ 細田 滋毅 \\ Shigeki Hosoda \\ 独立行政法人 海洋研究開発機構 \\ Japan Agency for Marine-Earth Science and Technology \\ hosodasejamstec.go.jp \\ 小野 智司 \\ 鹿児島大学大学院 理工学研究科 情報生体システム工学専攻 \\ Department of Information Science and Biomedical Engineering,Graduate School of Science and Engineering, Kagoshima University \\ onodibe.kagoshima-u.ac.jp
}

keywords: ocean observation, sequential labeling, conditional random field, decision tree, feature function design

\section{Summary}

Globally-covered ocean monitoring system Argo with more than 3,700 autonomous floats has been working, and its accumulated big ocean observation data helps many studies such as investigation into climate change mechanism. Since the observed data sometimes involves errors, human experts must visually confirm and revise quality control (QC) flags. However, such manual QC by human experts cannot be performed in some countries. In addition, it is difficult to regularize the quality of the ocean observation data of all over the world because the manual QC depends on human experts' heuristics. Therefore, this paper proposes a method for error detection in Argo observation data using Conditional Random Field (CRF) because the problem requires consideration of sequence of both features and quality flags for accurate labeling in each depth. This paper also proposes a feature function design method using decision tree learning, allowing coping with various types of observation errors without manual work, whereas previous work had to focus on certain error types due to manual labor for feature function design. Furthermore, the proposed method divides the two CRF-based sequential classifiers that use manually- or automatically-designed feature functions respectively rather than combining the both feature functions into a single set. Experimental results have shown that the proposed method could detect all types of salinity errors with higher accuracy of QC flags assignments than the actually operated system in Argo project. In particular, the recall rate of the proposed method was better than that of CRF using the manually designed feature functions even for the specific error types for which they were designed.

\section{1. は じめに}

異常気象の一因とされる気候変動のメカニズムは未だ 十分に理解されていないが, 変動の駆動源として, 海洋 が強く関与していると考えられている.これは, 地球表 面上のおよそ 7 割を占める海洋が大気の 1,000 倍以上の 熱容量を持ち, 大気の状態を大きく変化させうるためで ある.このため, 海洋内部の変動を把握することは, そ れ自体の理解や水産業等の発展のみならず, 長期的な気 象の変動の予測やその仕組みの解明に寄与する．従来は 船舶による計測が主体であったが，コストが高く, 全世 界の海洋内部を網羅的かつ継続的に観測を行うことは困 難であった。

2000 年より全球観測データのリアルタイムな取得を目
的として，全球海洋監視システム「アルゴ」の運用が開 始された [Argo Data Management Team: Roemmich 01, Argo Data Management Team 02, Hosoda 12]. このシス テムでは, 全球観測網を実現するために，アルゴフロー トと呼ばれる自動昇降可能な海洋観測ロボット（図 1)を 海へ投入し, 海洋内部の水温や塩分の自動観測を行って いる．観測データが衛星を介して地上局に送られると， 品質管理が施され，インターネットを通じて公開される. 現在，このプロジェクトには全世界で 30 力国以上が参加 し，アルゴフロートは 3,700 台以上が常に稼動している. 現在までに 100 万点を遙かに超えるプロファイルの蓄積 に成功しており, 従来知り得なかった地球規模の変動が 捉えられ，気候変動のメカニズム解明に向けて研究が進 められている. 2007 年にはエルニーニョ現象・ラニーニャ 

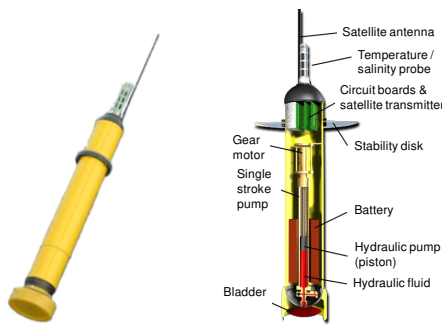

図 1 アルゴフロート
現象と並んで地球規模の気候変動をもたらすインド洋ダ イポールモード現象の予測に成功している [Tozuka 07]. さらなる気候変動や海洋環境変動の解明に向け, 二酸化 炭素やクロロフィルといった新たな観測量の導入も始め られている.

アルゴフロートにより自動観測されたデータには，約 10\%程度の割合で観測エラーが含まれる。アルゴデータ に含まれるエラーは，ハードウェアやソフトウェアに起因 するもの，センサ污濁やデータ受信の不具合などの外的 要因に起因するものなどがある．海洋に投入後のアルゴ フロートのデータ精度を直接評価することは困難である ため，観測值に対して様々な歴史的観測データ [Antonov 06, Locarnini 16] 等を用いて観測エラーを検出し，補正 を行う品質管理が行われている [Carval 12]. しかし，自 動品質管理によって全ての観測エラーを検出することは 困難であり，最終的に専門技術者により目視で確認が行 われている。このため，専門技術者ごとの補正基準の相 違や心的要因による判断の摇らぎ，人的資源が確保でき ない，あるいは補正スキルを持ち合わせていない国の存 在など，全球データの品質の均一性が担保できない点が 問題となっている [細田 13]. これらは国際アルゴ計画に おける長年の大きな課題であり, 全球海洋環境モニタリ ングの精度・信頼性に関わるほど重大である.

本研究では，全球データの品質均一化と高精度化を目 的とし，海洋データの観測エラーを検出する方式を提案 する. 提案する方式では，アルゴフロートによる観測デー タを深度方向の系列データとみなし，系列ラベリングを 行うことで観測エラーの検出を行い，各観測值に品質管 理フラグをラベルとして付与する．海域や深度等による 自然変動要因と比較して観測エラーのパターンは微小で あるため，観測エラーを検出するためには，対象となる 観測值に加えて深度や密度等の他の指標を参照する必要 がある.このため，提案する方式では，隠れマルコフモ デル (Hidden Markov Model: HMM) [Seymore 99] 等と 比較して多様な説明変数をもとにラベリングを行える条 件付確率場 (Conditional Random Field: CRF) [Lafferty 01]を用いて系列ラベリングを行う。また，観測エラーパ ターンが深度に強く依存するため，単純で多数の素性関 数を用いる代わりに，依存性を明示的に考慮した素性関 数を設計する必要がある [Kamikawaji 16b]。このため,
表 1 アルゴ観測エラーの分類

\begin{tabular}{|c|c|c|c|}
\hline エラーの種類 & プロファイル数 & 内訳 & プロファイル数 \\
\hline 密度逆転 & 1,253 & 負側密度逆転 * & 1,039 \\
\hline & & 正側密度逆転 * & 203 \\
\hline & & 正負両側 & 11 \\
\hline 同值 * & 309 & 同值エラー単体 * & 220 \\
\hline & & 密度逆転と混在 * & 89 \\
\hline 外れ值 * & 352 & \multicolumn{2}{|c|}{1} \\
\hline 水圧エラー & 1,282 & \multicolumn{2}{|c|}{-} \\
\hline 浅層エラー & 2,156 & \multicolumn{2}{|c|}{-} \\
\hline \multirow[t]{5}{*}{ 全体層エラー } & \multirow[t]{5}{*}{1,494} & ジグザグ & 63 \\
\hline & & オフセット* & $\overline{660}$ \\
\hline & & センサ経時変化 & 223 \\
\hline & & 外的要因 & 3 \\
\hline & & その他 & 545 \\
\hline $\begin{array}{l}\text { 連続エラー } \\
\text { (10 層以下) }\end{array}$ & 1,655 & \multicolumn{2}{|c|}{ 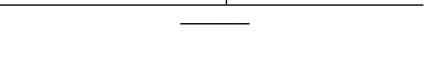 } \\
\hline 原因不明 & 134 & \multicolumn{2}{|c|}{$\longrightarrow$} \\
\hline フラグ 9 のみ & 328 & \multicolumn{2}{|c|}{-} \\
\hline 合計 & 8,963 & \multicolumn{2}{|c|}{$\longrightarrow$} \\
\hline
\end{tabular}

パターンが比較的明確な一部の観測エラーに対しては手 動で素性関数を設計し，その他の分類が困難なエラーに 対しては，決定木学習を行うことで自動的に素性関数を 設計する.さらに，得られた 2 種類の素性関数集合が対 象とする観測エラーの種類はそれぞれ異なり, CRF で用 いる重みベクトルを同時に学習を行うと, 観測エラー間 の影響度の強さ（深度方向の影響範囲）や発生頻度の違 いによる不均衡性の影響を受けてしまう。このため, 2 種 類の素性関数集合をそれぞれ用いる 2 つの識別器を個別 に学習し, 予測結果を統合する形式をとる. 以上のよう な構成をとることで, 多様な観測エラーを高い精度で検 出する方式を実現することが可能となる. 評価実験を行 い，専門技術者による品質管理が高い水準で行われてい る北太平洋海域で観測されたデータに対して提案方式を 適用し，アルゴプロジェクトで現在運用されている自動 品質管理方式よりも高い品質で観測エラーを発見できる ことを示す.

以下， 2 章ではアルゴ観測システムの概要および観測 エラーの詳細について述べる，3 章では，提案する系列 ラベリング手法の詳細について述べ，処理手順や素性関 数の自動設計等の特徵的な処理について説明する.4 章 では北太平洋海域で観測されたデータを対象として評価 実験を行い，提案する方式の有効性を検証する.

\section{2. 関 連 研 究}

\section{$2 \cdot 1$ 全球観測システム アルゴ}

アルゴフロートによる観測サイクルを図 2 に示す。ア ルゴフロートは海に投入されると, 海流の影響が弱い水 深 $1,000[\mathrm{~m}]$ で漂流する．観測時になると，水深 2,000 [m] 付近まで降下し，水温と塩分を観測しながら海面まで浮 上する. 1 回の浮上によって生成される観測データはプロ ファイルと呼ばれ，プロファイルには鉛直約 100 層分の 水温值および塩分值が記録される.アルゴフロートは, こ 


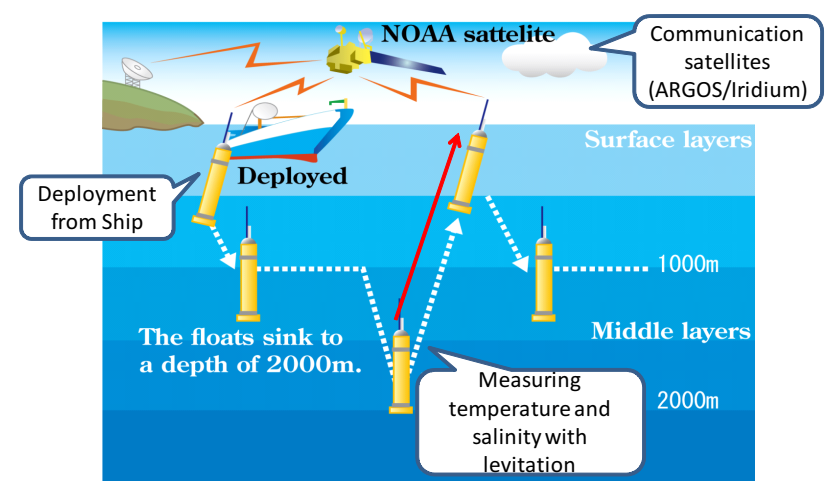

図 2 アルゴフロートによる観測の流れ

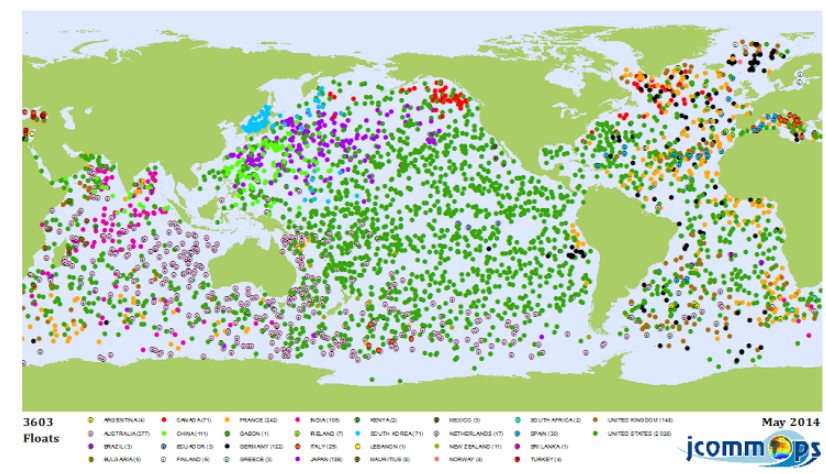

図 3 アルゴフロートの稼働状況

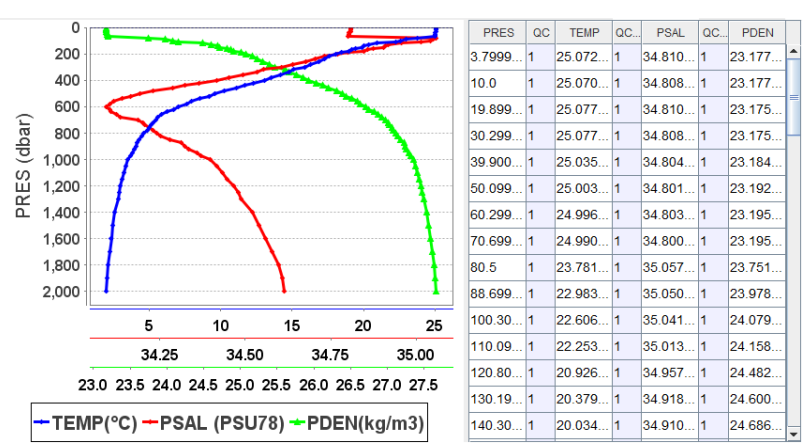

図 4 プロファイルの例

の観測サイクルを 10 日間隔で自動的に行う．プロファイ ルの例を図 4 に示す．縦軸は圧力 $[\mathrm{dbar}]$ であり，これは 水深 $[\mathrm{m}]$ とおよそ同義である. 青色のグラフは水温 $\left[{ }^{\circ} \mathrm{C}\right]$, 赤色のグラフは塩分 [PSS-78], 緑色のグラフは水温と塩 分から算出される密度 $\left[\mathrm{kg} / \mathrm{m}^{3}\right]$ を表す。

アルゴにおける品質管理では，アルゴフロートによっ て観測されたプロファイルに対して観測值の信頼度を決 定する．品質管理フラグの種類として，1（正），2（お そらく正)，3(おそらく誤），4（誤）の4段階の信頼度 が使用される。

品質管理には，即時品質管理 (Real-time quality control: RQC）と遅延品質管理（Delayed-mode QC: DQC）の 2 種類がある [Argo Data Management Team 12]. RQC は プロファイルが観測されてから 24 時間以内に観測デー
タを公開することを目的として，簡易的に行われる品質 管理である.リアルタイムなデータの公開を優先するた め，技術者による目視確認が行われないことが多い。一 方, DQC は研究や解析用のデータとして提供することを 目的として行われる高精度な品質管理である．専門技術 者により観測されたプロファイルや近傍で観測されたプ ロファイルとの比較などを含めて目視確認が行われ，必 要に応じて補正が行われる。

既存の自動品質管理方式は，観測方法に関する規定は 詳細に定められているものの，季節や天候などの自然変 動による影響が水温や塩分といった観測量を激しく変化 させるため，観測量に対する記述は比較的少ない状態に ある。これは，季節や天候などの自然変動による影響が 水温や塩分といった観測量を激しく変化させるためであ り，データ品質管理方式の記述が困難となっている．既 存の自動品質管理方式では全てのエラーに対応すること は技術的に難しく，エラーの見落としや誤検出が発生し ている.最終的に専門技術者による目視確認ならびに手 動補正が行われているが，技術者の大きな負担となって いる.

さらに，人間の判断が介入することによってデータ品 質の均一性が崩れるという問題を誘発する．技術者によ り補正の基準やスキルに相違があることや，心的要因に よる判断基準の摇らぎ，技術者不足により補正ができな い国の存在など，全球アルゴ観測網にとって重要として いるデータの均一性を担保することが困難である。また， 品質管理方式に変更点が生じると，それまでに品質管理 を施したプロファイルを再度確認する必要が出てくるが, 人的資源も限られているため難しい。これらは国際アル ゴ計画における大きな課題であり, 全球海洋環境モニタ リングの精度・信頼性に関わる.

\section{$2 \cdot 2$ アルゴ観測データにおけるエラー}

アルゴフロートが観測を行い, 本研究の品質管理の対 象となる指標は, 水深 (水圧), 水温, 塩分の 3 種類であ る.このうち, 塩分に関するエラーが最も多いため, 本 研究では塩分に関する品質管理フラグの推定を行う。ア ルゴフロートによる塩分に関するエラーの分類例を表 1 に示す．なお，表 1 の分類は，海洋学的な知見に基づく 分類ではなく, 本研究において便宜上行った分類である ことに留意されたい，また，表 1 に示したプロファイル 数は, 北太平洋域で国立研究開発法人海洋研究開発機構 によって遅延品質管理が行われたプロファイルの数を表 している.

表 1 に示す観測エラーのうち，*印が付与された観測 エラーは専門技術者へのヒアリングによりパターンの傾 向が明確化可能であることが判明した観測エラーであり， 密度逆転（図 5), 同值エラー, 外机值, オフセット（図 6）の 4 種類が該当する.

密度逆転とは，深度とともに単調増加するはずの密度 


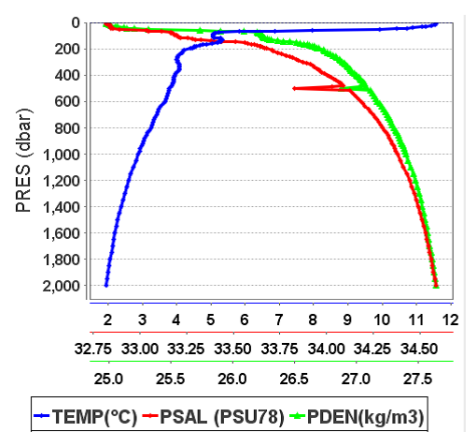

(a) 密度逆転の例 1
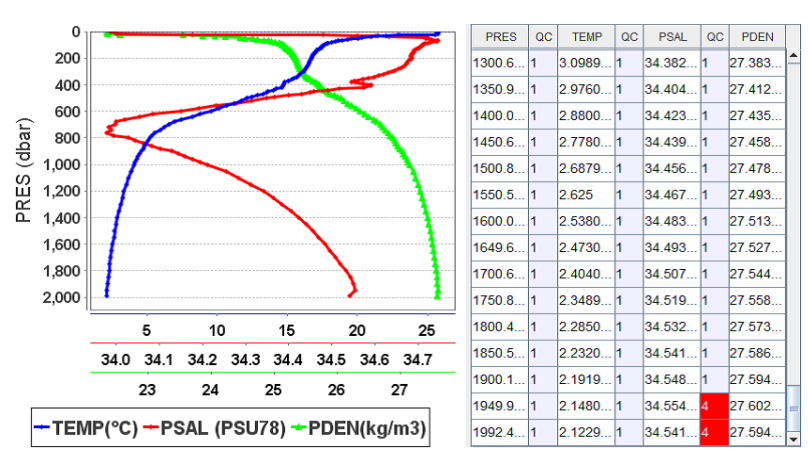

(b) 密度逆転の例 2

図 5 密度逆転の例
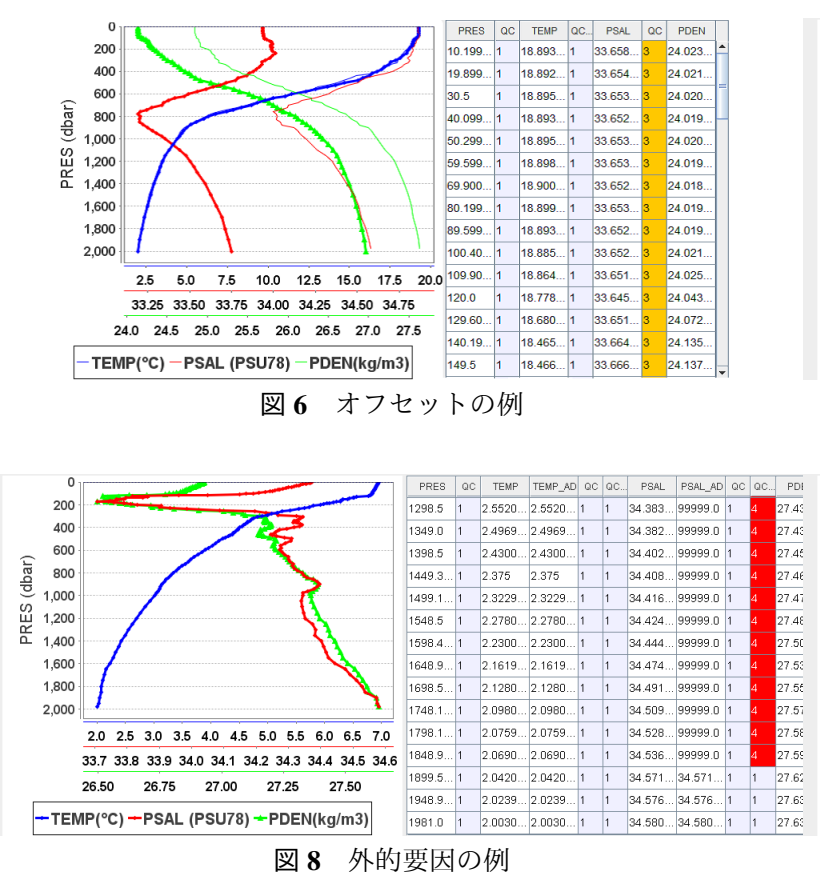

が逆転し，連続する観測層において深い層の方が密度が 低い值が観測されたエラーを指す．密度は，水温，塩分に よって決定される值で, 海域によらず深度とともに単調 増加するという傾向がある．密度逆転は，アルゴフロー トの観測データの場合は一般的に，ハードウェアやソフ トウェアの問題, 污濁物質や生物の付着などの環境場に 起因して発生する.

同值エラーとは，アルゴフロートが観測する際に，電 圧低下により観測が行われず，直前に観測した值がその ままコピーされる観測不良を指す。すなわち，連続した観 測層で同じ観測值が格納されていることになる。ただし， 連続した観測層間の水圧值の差が小さい場合はエラーで ない可能性が高いため許容され，フラグ 4 が割り当てら れないことがある。

外れ值とは，観測した值が正常な範囲を外れている場 合を指す。これらの観測エラーでは，単層にのみ観測エ ラーを表す品質管理フラグ 4 を割り当てることが多い.
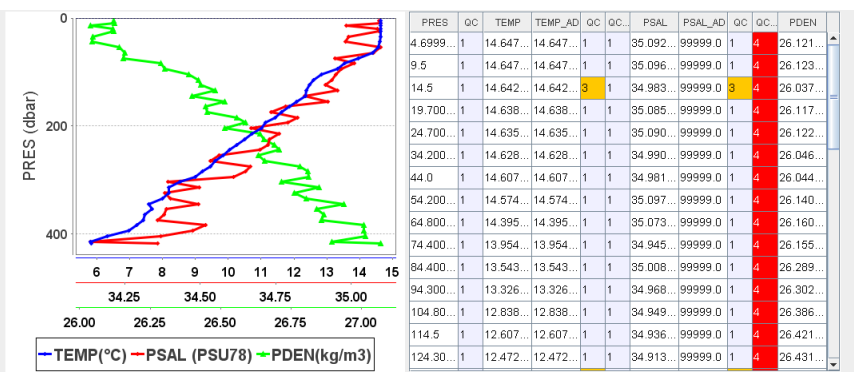

図 7 ジグザグの例
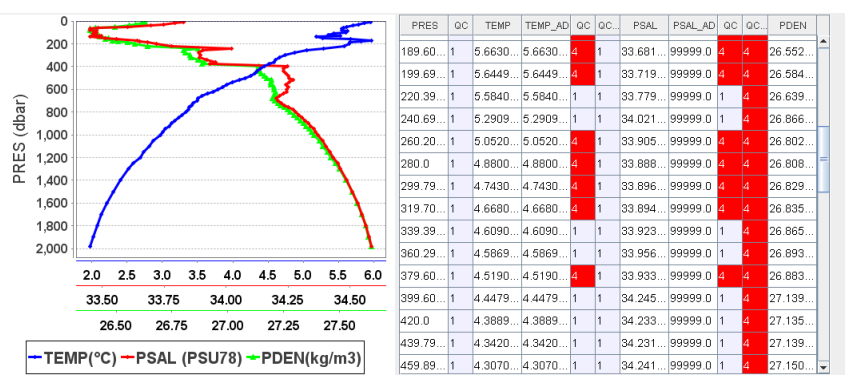

図 9 原因不明の観測エラーの例

一方, オフセットは, 図 6 に示すように, 過去のプロ ファイルや近傍プロファイルと比較したとき， 観測量の グラフ全体が平行移動したような観測值が得られる観測 エラーである. ハードウェアや観測センサなどの問題に より突発的に起こることがあり，一般的にオフセットが 一度発生すると以降の観測の際もエラーが発生し続ける. オフセットは観測層全体に現れる場合や，深層のみに現 れる場合もあり, 自動品質管理では検出対象外とされて いる.

以上のような専門技術者により分類が可能な観測エラー のほかに, 図 7, 図 8, 図 9 に示すような観測エラーが 存在する. 水深が浅い層においては, 季節や天候の要因 を受けて観測值が激しく変動し, 正常な観測值か観測エ ラーであるかの判別が難しい，専門技術者の経験と直感 で判別が行われることもあり, 本研究では, これらを浅 層エラーと分類する. 図 7 は観測層全体に正負交互の方 向に鋭角的な変動を繰り返し含む観測エラーであり，ジ 
グザグと呼ぶ. また, 図 8 に示すように, 何らかの理由 によりプロファイル内の多層にわたり観測エラーが生じ ることもある. 本研究では，あるフロートが継続して観 測エラーを出力する場合はセンサ経時変化と呼び, 逆に, 1 回の観測のみで前後のプロファイルは正常な場合は外 的要因と呼ぶ. その他, 図 9 のように原因や分類が困難 な観測エラーが存在する.

\section{$2 \cdot 3$ 機械学習を用いたアルゴ観測データの品質管理の 試み}

2013 年度人工知能学会全国大会におけるオーガナイズ

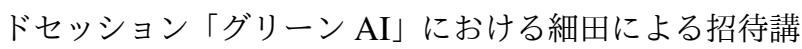
演 [細田 13] を契機として，アルゴ観測データに対して 機械学習を適用する試みが始まった。著者らは，専門技 術者にヒアリングを行い, 表 1 で‘*’, 印が付与された観 測エラーを対象として, CRFにより観測エラーを検出す る方法を提案した [松山 14, 松山 15, Ono 15]. また, 海 洋観測データでは観測エラーのパターンが深度に強く依 存し, 説明変数を 1 個のみ含む単純な素性関数を多数用 意する CRF では，十分なラベリング精度が得られない ことを確認した [Kamikawaji 16b] . 例えば, 密度逆転を 例にとると, 浅い層では大きな幅の密度逆転であっても エラーとみなされないが, 深い層では非常に小さな幅で あってもエラーとみなされる。これは, 浅い層では海上 の条件 (季節，天候等）を強く受けるため密度が安定しな いが，深い層では上記のような影響を受けないため，観 測值が極めて安定しているためである.このため, 著者 らは, 決定木学習を用いて説明変数間の依存性を考慮し た素性関数を自動的に設計する方式を検討し，全ての種 類の観測エラーを対象として検出を行えることを示した [上川路 16a, Kamikawaji 16b] .

本論文は, 上記の研究による成果を集約したものであ り，さらに，対象となる観測エラーパターンの明確さに 応じて設計された 2 種類の素性関数集合を用いて系列ラ ベリングを行う方式を新たに提案し，その効果を示す.

一方，林らは正例のみからの異常検出の考え方に基づき， 観測エラーを検出する方法の実現を試みている [Hayashi 16, 林 18]. 階層的クラスタリングと近傍法の組み合わ せにより，未知の観測エラーにも対応できる点に特徴が ある。

\section{3. 提 案 方 式}

\section{$3 \cdot 1$ 基本アイデア}

本研究では, アルゴフロートによる観測データの品質 の向上および均一化を目指し，品質管理フラグの良否判 別を系列ラベリング問題と捉え, 以下のアイデアに基づ く系列ラベリング方式を提案する.

アイデア 1: 条件付確率場（CRF）を用いて系列ラベ リングを行う.
多様な属性を参照しつつ，前後のラベルの組み合わせを 考慮した良否識別を行うために，提案方式は CRF を用 いて系列ラベリングを行う。 CRF は，HMM と比較して， 様々な素性を同時に考慮できる点に特徴がある。特に， $2 \cdot 3$ 節で述べたように，本問題における観測エラーのパ ターンは深度に強く依存する。このため, 個々の説明変 数のみに着目した単純な素性関数を列挙するのではなく， 専門技術者へのヒアリングを行った結果に基づいて，説 明変数間の依存性を考慮した条件を持つ素性関数を作成 する.

アイデア 2: 決定木学習を用いて素性関数集合を自動 設計する。

$2 \cdot 2$ 節で述べたように，アルゴデータでは密度逆転や複 数層同值観測などのパターンが比較的明確な観測エラー のほかに，専門技術者であってもパターンの定義や分類 が困難な観測エラーが多い，加えて，対象問題は深度や 海域に依存する自然変動パターンに対して観測エラーパ ターンが微小であり，単純な多数の素性関数集合では検 出が困難な観測エラーが存在する.このため, 本研究で は，決定木学習を行うことで CRF の素性関数の自動設 計を試みる．決定木学習により，複数の属性を考慮した 複雑な素性関数を自動的に構築することが可能となる. また，決定木を観測エラーの検出に直接用いるかわりに， CRF の素性関数として利用することで，連続する観測層 にまたがる観測エラーを推定することが可能となる.

アイデア 3: 2 種類の素性関数集合を個別に利用する. 上記で述べたように，提案方式は，手動で設計された素 性関数と，自動設計された素性関数の双方を利用する．前 者は観測エラーが生じる層数が比較的少なく，後者は比 較的多い観測層にエラーが影響することが多いこと，お よび，観測エラーによって出現頻度に差異があることか ら，2 種類の素性関数集合を統合して学習を行うと，発 生頻度が低く，影響範囲が小さい観測エラーを検出しな いように学習が行われてしまう。このため，提案方式で は，2つの素性関数集合を統合して CRF の重みを学習す るかわりに，それぞれの素性関数集合の重みを個別に学 習し，2つの独立した CRF を用いて観測エラーを検出す る。これにより, 観測エラー間の出現頻度や，エラーが 影響する観測層の範囲の不均質さに起因する困難さを回 避して素性関数の重みの学習を行うことが可能となる.

\section{$3 \cdot 2$ 処 理 手 順}

提案する方式の処理手順を図 10 に示す。学習を行う 際は, 観測エラーの発生頻度の低さによる不均衡性に対 処するため，観測エラーを含むプロファイルのみを用い る. まず，本来は深度方向の系列を有する系列ラベリン グ問題である本問題を, 観測層ごとに個別にエラーの有 無を検出する点推定の識別問題とみなし，全種類の観測 エラーを含む訓練データセットに対して，決定学習を適 用する.これにより得られた決定木をもとに，3.5 節で 


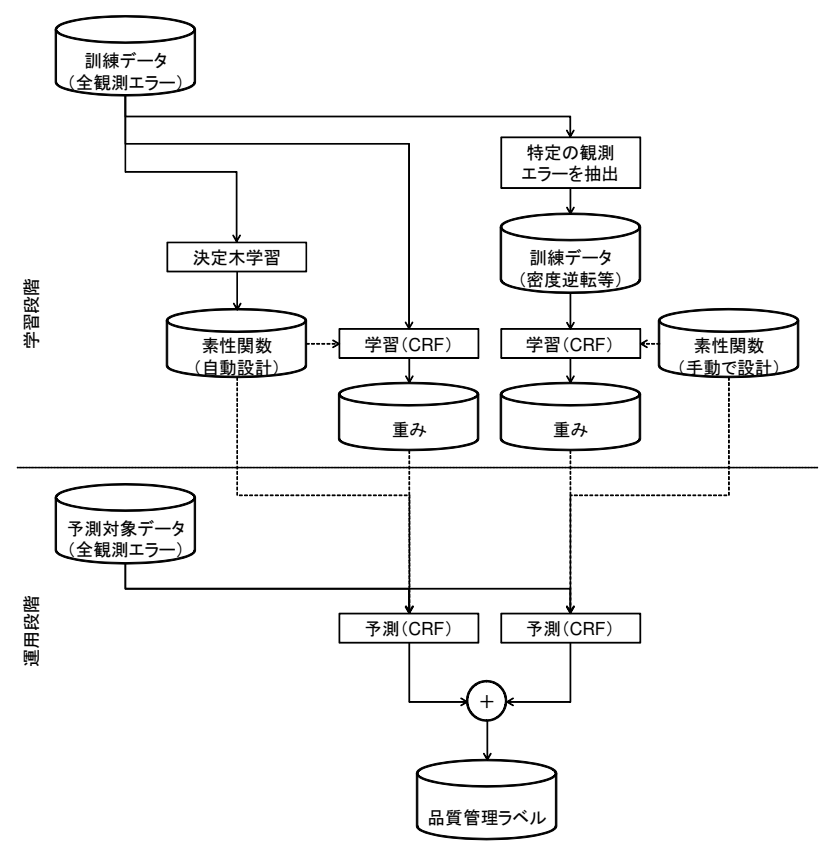

図 10 提案する方式の構成と処理手順

述べる手順に従って, 素性関数集合を得る. 次に, 得られ た素性関数集合を用いて，3.3 節で述べる一般的な CRF の学習手順に従って素性関数の重みの学習を行う.

また，全種類の観測エラーを含む訓練データセットか ら, 密度逆転, 同值エラー, 外れ值の 3 種類の観測エラー のみを含むプロファイルを抽出し，部分訓練データセッ トを作成する，上記の部分訓練データセットを用いて，専 門技術者へのヒアリングに基づいて事前に手動で設計し た素性関数（3.4 節）の重みを学習する.

以上のようにして，CRF を用いた 2 種類の独立した識 別器を構築する.

実運用段階において観測エラーの検出を試みる際は, 上記の 2 種類の識別器を適用し, 層毎に予測結果の論理 和*1をとることで観測值に対する品質管理フラグを決定 する.

\section{$3 \cdot 3$ 条件付確率場を用いた系列ラベリング}

条件付確率場（CRF）は系列ラベリング問題に用いら れる識別モデルであり [Lafferty 01], 系列データやラベ ルの前後の依存関係の特徵を素性として記述できるため, 多様な属性を参照しつつ, 前後のラベルの組み合わせを考 慮したラベリングを行うことができる. CRF ではラベル 間の依存関係に応じて様々なモデルが存在するが，本稿で は入力データと 1 つ前のラベルに依存する Linear-chain モデルを前提に説明する.

系列の長さが $T$ である入力データ $\boldsymbol{x}=\left(x_{1}, x_{2}, \ldots, x_{T}\right)$ が与えられたとき, 出力ラベル $\boldsymbol{y}=\left(y_{1}, y_{2}, \ldots, y_{T}\right)$ とな る条件付確率 $P$ を式(1)のようにモデル化する [Lafferty

*1 フラグ 1 （正）を 0, ラベル 4 （誤）を 1 として論理和をと る.
01, Sutton 12] .

$$
P(\boldsymbol{y} \mid \boldsymbol{x})=\frac{1}{Z_{\boldsymbol{x}}} \exp \left(\sum_{t} \sum_{k} \lambda_{k} f_{k}\left(\boldsymbol{x}, y_{t}, y_{t-1}\right)\right)(1)
$$

ここで, $f_{k}$ は素性関数, $\lambda_{k}$ は素性関数 $f_{k}$ に対する重み, $z_{\boldsymbol{x}}$ は $\sum_{y} P(\boldsymbol{y} \mid \boldsymbol{x})=1$ を保証する正規化係数である. 素 性関数 $f_{k}$ は識別器を学習させる際に, 識別の情報とし て与える特徴量であり, 式 (2)のように定義される.

$$
f_{k}\left(\boldsymbol{x}, y_{t}, y_{t-1}\right)= \begin{cases}\phi_{k} & \text { if condition }=\text { true } \\ 0 & \text { otherwise }\end{cases}
$$

ここで, $\phi_{k}$ は素性值と呼ばれる実数值であり, 素性に応 じて任意に設定できる. 素性関数は入力 $\boldsymbol{x}$ および $t$ 番目 と $(t-1)$ 番目の出力ラベルに依存しており, 問題に応じ て設計する.

学習では入力データ $\boldsymbol{x}$ と出力ラベル $\boldsymbol{y}$ を 1 組とする 学習データ $\boldsymbol{D}=\left\{\left(\boldsymbol{x}^{(i)}, \boldsymbol{y}^{(i)}\right)\right\}_{i=1}^{N_{D}}$ を与え, 勾配法により, 条件付確率 $P$ の最尤推定をとった目的関数 $L(\boldsymbol{\lambda})$ を最適 化し, パラメータである $\boldsymbol{\lambda}=\left(\lambda_{1}, \lambda_{2}, \ldots \lambda_{N_{k}}\right)$ を求める.

$$
L(\boldsymbol{\lambda})=\sum_{i} \log P\left(\boldsymbol{y}^{(i)} \mid \boldsymbol{x}^{(i)}\right)-\sum_{k} \frac{\lambda_{k}^{2}}{2 \sigma^{2}}
$$

ここで, 式 (3) の第 2 項は過学習を防ぐための正規化項 である.

学習した識別器を使って, 入力データ $\boldsymbol{x}$ に対する出力 ラベル $\boldsymbol{y}_{\text {out }}$ を決定する際は, 式 (4) に示す最大化問題を 解くことにより決定する.

$$
\boldsymbol{y}_{\text {out }}=\underset{\boldsymbol{y}}{\operatorname{argmax}} P(\boldsymbol{y} \mid \boldsymbol{x})
$$

\section{$3 \cdot 4$ 手動で設計された素性関数}

専門技術者にヒアリングを行って手動で設計した素 性関数集合を表 2 に示す. PRES $S_{t}$ は圧力 $[\mathrm{dbar}]$ であ り, 注目する観測層の水深を表す. $T E M P_{t}$ は水温 $\left[{ }^{\circ} \mathrm{C}\right]$, $P S A L_{t}$ は塩分 $[\mathrm{PSS}-78], P D E N_{t}$ は水温および塩分か ら算出された密度であり, 添え字 $t$ は観測層を表す。 また, $P D E N_{\max }$ は $(t-1)$ 層目までの最大密度值, $P D E N_{\min }$ は $(t+1)$ 層目以降の最小密度值を表す.

表 2 における $f_{1}$ は塩分値のとりうる許容範囲を表す 素性であり, 出現回数が多いことを考慮して素性值 $\phi_{1}$ を 観測層数 $T$ の逆数とする. $f_{2}$ は塩分值が許容範囲外の 場合を表す． $f_{3}$ は，水深が $800[\mathrm{dbar}]$ より深い場合にお いて，連続した層で観測值が同值であることを表す素性 である. $f_{4}$ は複数の観測において水深值が同じ值である ことを表す. $f_{5}, f_{6}, \ldots, f_{10}$ は, 密度逆転に関する観測エ ラーを表す素性である。密度逆転を扱う素性は閾值の設 定が難しく，専門技術者の知見に従い，水深 $1,400[\mathrm{dbar}]$ を境に異なる閾值を設けている. 
表 2 手動で設計した素性関数集合 [Ono 15]

\begin{tabular}{c|l|l|c}
\hline No. & 対象観測エラー & 条件 & 素性値 $\phi_{k}$ \\
\hline$f_{1}$ & 正常 & $2 \leq P S A L_{t} \leq 41$ & $1 / T$ \\
\hline$f_{2}$ & 範囲外 & $P S A L_{t}<2,41<P S A L_{t}$ & 1.0 \\
\hline$f_{3}$ & 同值 & $P S A L_{t}=P S A L_{t+1}, T E M P_{t}=T E M P_{t+1}, P R E S_{t}<P R E S_{t+1}, 1,600<P R E S_{t}$ & 1.0 \\
\hline$f_{4}$ & 同值 & $P S A L_{t}=P S A L_{t+1}, T E M P_{t} \neq T E M P_{t+1}, P R E S_{t}=P R E S_{t+1}$ & 1.0 \\
\hline$f_{5}$ & 密度異常 & $P R E S_{t} \leq P R E S_{t-1}$ & 1.0 \\
\hline$f_{6}$ & 密度異常 & $P R E S_{t+1} \leq P R E S_{t}$ & 1.0 \\
\hline$f_{7}$ 密度逆転 & $P D E N_{t}-P D E N_{\max }<-0.01, P R E S_{t} \leq 1,400$ & 1.0 \\
\hline$f_{8}$ & 密度逆転 & $P D E N_{t}-P D E N_{\max }<0,1,400<P R E S_{t}$ & 1.0 \\
\hline$f_{9}$ 密度逆転 & $P D E N_{t+1}-P D E N_{t}<-0.01, P R E S_{t} \leq 1,400$ & 1.0 \\
\hline$f_{10}$ & 密度逆転 & $P D E N_{t+1}-P D E N_{t}<0,1,400<P R E S_{t}$ & 1.0 \\
\hline
\end{tabular}

\section{$3 \cdot 5$ 決定木学習を用いた素性関数の自動設計}

決定木は予測モデルの一種であり, 決定木を学習デー タから構築することで分類や回帰を行うことができる. 決定木では，根を起点とし，(根を含む）節に対応する説 明変数の值によって分岐を繰り返し, 到達した葉によっ て目的変数の予測值を得る. 分類問題では, 葉はクラス を表し，枝がそのクラスに至るまでの条件を示す.

本研究では, アルゴ観測データを深度方向の系列デー タとみなし，系列ラベリングを行うことで観測エラーの 検出を行い, 各深度の観測值に 品質管理フラグをラベ ルとして付与する。一方で, 決定木学習を行って素性関 数集合を設計する際は, 観測層ごとに独立して 品質管 理フラグを付与する（点推定を行う）識別問題として考 え, 決定木学習を適用する. 得られた決定木の各葉ノー ドについて，葉ノードから根ノードに至るノードの集合 を素性の条件式とすることで, 素性関数集合を構築する. なお，正常な観測值に関する基本的な素性が必要である ため, 表 2 に示す $f_{1}$ のみは, 得られた決定木の構成と は関係なく素性関数集合に追加する.

提案方式において，決定木学習を行う際に用いる説明 変数を表 3 に示す. 注目する観測層の観測值および前後の 層との差分を基本的な説明変数とし, 比較的離れた観測 層の情報を参照するために, $P D E N_{\max }$ や $P D E N_{\min }$, World OceanAtlas [Locarnini 16] の緯度, 経度, 深度の平 均塩分を加えている. 決定木を学習するアルゴリズムは, Gini 不純度が低下するように分岐条件を定める CART (Classification and Regression Trees) [Olshen 84] 用い る.

\section{4. 評 価 実 験}

\section{1 実 験 条 件}

提案する方式の有効性を検証するために, 現在アルゴ プロジェクトで実運用されている即時品質管理（RQC） との比較を行った。また，自動設計された素性関数集合 のみを用いる CRF，手動で設計を行った素性関数集合の みを用いる CRF， 2 種類の素性関数を 1 つの集合にまと めて学習を行う CRF との比較も行った.

RQC: アルゴプロジェクトで実際に運用されている自 動品質管理方式.

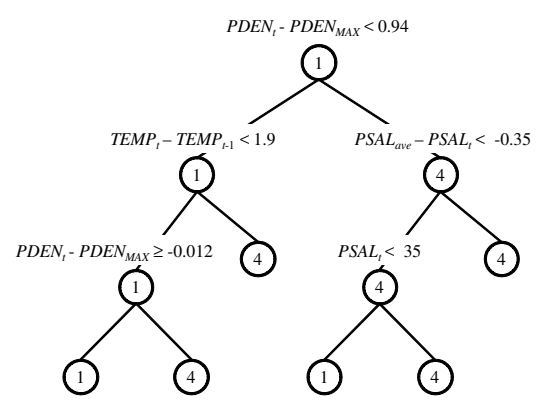

(a) 多くの試行で得られた決定木 $P D E N_{t}-P D E N_{\text {MAX }}<0.94$

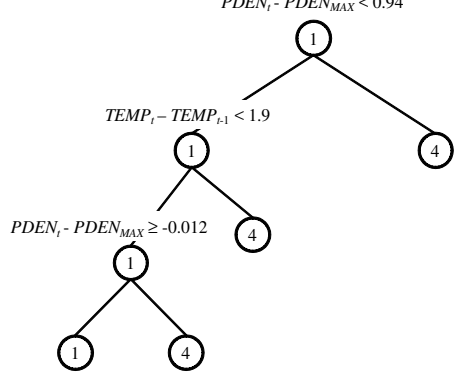

(b) 例外的に得られた決定木

図 11 生成された決定木の例

$\mathrm{CRF}_{\mathrm{MD}}$ : 密度逆転, 複数層同值, 範囲外等のパター ンが比較的明確な観測エラーのみを対象として，専門家 へのヒアリングに基づき手動で設計を行った素性関数集 合 $S_{M D}$ のみを用いる $\mathrm{CRF}$ （国際会議論文を引用予定）.

$\mathrm{CRF}_{\mathrm{DT}}$ : 専門家が分類困難な観測エラーを含む全て の観測エラーを対象として，決定木学習によって自動設 計された素性関数集合 $S_{D T}$ のみを用いる CRF.

$\mathbf{C R F}_{\mathbf{M D}+\mathrm{DT}}: S_{M D}$ および $S_{D T}$ を 1 つに統合した素 性関数集合 $S_{M D+D T}$ を用いる $\mathrm{CRF}$.

$\mathbf{C R F}_{\mathrm{MD}}+\mathbf{C R F}_{\mathrm{DT}}$ (提案方式) : $\mathrm{CRF}_{\mathrm{MD}}$ と $\mathrm{CRF}_{\mathrm{DT}}$ を独立して適用する方式. 再現率を重視し，2 つの結果 の論理和を出力とする. すなわち，いずれかの CRF が 観測エラーラベルを付与した層に，観測エラーラベルを 付与する. $S_{M D}$ および $S_{D T}$ を 1 つの素性関数集合に統 合せず，それぞれを個別に用いて学習および観測エラー の推測を行う点が $\mathrm{CRF}_{\mathrm{MD}+\mathrm{DT}}$ とは異なる.

アルゴによる観測データには 1 （正）から 4（誤）まで の品質管理 フラグが付与されるが ${ }^{*}$, フラグ 2 および

*2 まれに付与されるフラグ 9 (欠損) については本実験の対象 


\begin{tabular}{|c|c|}
\hline 説明変数 & 内容 \\
\hline$P R E S_{t}$ & 注目している観測層 $t$ の深度（水圧） \\
\hline$T E M P_{t}$ & 注目している観測層 $t$ の水温 \\
\hline$P S A L_{t}$ & 注目している観測層 $t$ の塩分 \\
\hline $\mathrm{PDEN}_{t}$ & 注目している観測層 $t$ の密度 \\
\hline$P D E N_{t}-P D E N_{M A X}$ & 注目している観測層より浅い層における密度の最大值と $t$ 層の密度との差分 \\
\hline$P D E N_{M I N}-P D E N_{t}$ & 注目している観測層より深い層における密度の最小值と $t$ 層の密度との差分 \\
\hline$P R E S_{t}-P R E S_{t-1}$ & 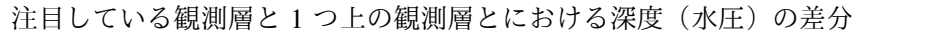 \\
\hline$T E M P_{t}-T E M P_{t-1}$ & 注目している観測層と 1 つ上の観測層とにおける水温の差分 \\
\hline$P S A L_{t}-P S A L_{t-1}$ & 注目している観測層と 1 つ上の観測層とにおける塩分の差分 \\
\hline$P R E S_{t}-P R E S_{t+1}$ & 注目している観測層と 1 つ下の観測層とにおける深度（水圧）の差分 \\
\hline$T E M P_{t}-T E M P_{t+1}$ & 注目している観測層と 1 つ下の観測層とにおける水温の差分 \\
\hline$P S A L_{t}-P S A L_{t+1}$ & 注目している観測層と 1 つ下の観測層とにおける塩分の差分 \\
\hline$T E M P_{A V E}-T E M P_{t}$ & プロファイル全体の水温の平均と注目する観測層の水温の差分 \\
\hline$P S A L_{A V E}-P S A L_{t}$ & プロファイル全体の塩分の平均と注目する観測層の塩分の差分 \\
\hline$P S A L_{W O A}$ & WOA[Locarnini 16] における該当する緯度, 経度, 深度の平均塩分 \\
\hline
\end{tabular}

表 4 決定木から作成した素性関数集合の例

\begin{tabular}{l|l|c}
\hline No. & 条件 & 素性值 $\phi_{k}$ \\
\hline$f_{1}$ & $2 \leq P S A L_{t} \leq 41$ & $1 / T$ \\
\hline$f_{2}$ & $P D E N_{t}-P D E N_{\max }<0.94 \wedge T E M P_{t}-T E M P_{t-1}<1.9 \wedge P D E N_{t}-P D E N_{\max } \geq-0.012$ & 1.0 \\
\hline$f_{3}$ & $P D E N_{t}-P D E N_{\max }<0.94 \wedge T E M P_{t}-T E M P_{t-1}<1.9 \wedge P D E N_{t}-P D E N_{\max }<-0.012$ & 1.0 \\
\hline$f_{4}$ & $P D E N_{t}-P D E N_{\max }<0.94 \wedge T E M P_{t}-T E M P_{t-1} \geq 1.9$ & 1.0 \\
\hline$f_{5}$ & $P D E N_{t}-P D E N_{\max } \geq 0.94 \wedge P S A L_{a v e}-P S A L_{t}<-0.35 \wedge P S A L_{t}<35$ & 1.0 \\
\hline$f_{6}$ & $P D E N_{t}-P D E N_{\max } \geq 0.94 \wedge P S A L_{a v e}-P S A L_{t}<-0.35 \wedge P S A L_{t} \geq 35$ & 1.0 \\
\hline$f_{7}$ & $P D E N_{t}-P D E N_{\max } \geq 0.94 \wedge P S A L_{a v e}-P S A L_{t} \geq-0.35$ & 1.0 \\
\hline
\end{tabular}

3 は曖昧さを含むラベルであるため，問題を単純化する ために，フラグ 1 および 2 を 1 に，フラグ 3 および 4 を 4 にそれぞれ統一することで 2 值のラベルを付与する問 題とした．実験に使用したプロファイルは，北太平洋域 で観測され, 国立研究開発法人海洋研究開発機構で遅延 品質管理が行われたプロファイルとし，DQCによる品質 管理フラグを真值とした。

アルゴデータにおける観測エラーの発生頻度は低く, 不 均衡データであるため, 観測エラーを含むプロファイル のみを利用して学習を行った。これは, 観測エラーを含 むプロファイルであっても，ごく一部の観測層にのみ観 測エラーを含み, 正常な観測值を多く含むプロファイル が多いため, 観測エラーを含まないプロファイルを学習 に利用しないことで不均衡の軽減を図るものである。な お，評価を行う際は，観測エラーを含むプロファイルに加 えて観測エラーを含まないプロファイルを追加した。こ れは，観測エラーを含まないプロファイルにおける誤検 出についても評価を行うためである.

塩分の観測エラーを含む 8,223 プロファイル $* 3$ を全観 測エラーを含むデータセット $D_{\text {all }}$ とした. 10 分割交差検 定を行い，各方式の予測性能を比較することとした。な お，予測性能を評価する際は，通常の交差検定とは異な り，評価用サブセットに加えて，観測エラーを含まない プロファイルを同数用意することとした. すなわち, 学 習に利用していない（観測エラーを含む） 823 プロファイ ルと，観測エラーを含まない（ $D_{\text {all }}$ に含まれない） 823

外とした。

*3 表 1 において,「フラグ 9」の項目に記された 328 プロファイ ル以外に，他の項目に分類されたプロファイルにもまれにフラ グ 9 を含むことがあり，合計で 740 プロファイルを除外した。
プロファイルとの合計 1,646 プロファイルを用いて評価 を行った。観測エラーを含まない 823 個のプロファイル は, 10 分割サブセットごとに異なるプロファイルをラン ダムに選出した。

評価は観測層単位で行うこととし，観測エラーを正しく 検出した場合（フラグ 4 を付与した場合）を真陽性（TP）, 観測エラーの検出に失敗した場合を偽陰性（FN），正常 な観測值を誤って観測エラーとして検出した場合を偽陽 性（FP）, および, その他を真陰性（TP）とし, 再現率, 適合率, F1 score を算出した。

\section{$4 \cdot 2$ 実 験 結 果}

\section{$\S 1$ 決定木学習により設計された素性関数}

$\mathrm{CRF}_{\mathrm{DT}}, \mathrm{CRF}_{\mathrm{MD}+\mathrm{DT}}$, および $\mathrm{CRF}_{\mathrm{MD}}+\mathrm{CRF}_{\mathrm{DT}}$ で 用いる素性関数集合 $S_{D T}$ を決定学習により自動設計を 行った. 全観測エラーを含むデータセット $D_{\text {all }}$ を対象と して決定木の生成を試みたところ，10 分割中 8 分割に おいて図 11(a) の決定木が得られ, 残りの 2 分割におい ては図 11(b) に示すような構造の異なる決定木が得られ た。図 11(a) から得られた素性関数集合 $S_{D T}$ の例を表 4 に示す. 各分割で得られた決定木を $S_{D T}$ として, 次節の $\mathrm{CRF}_{\mathrm{DT}}, \mathrm{CRF}_{\mathrm{MD}+\mathrm{DT}}$, および $\mathrm{CRF}_{\mathrm{MD}}+\mathrm{CRF}_{\mathrm{DT}}$ で用 いることとした。

\section{$\S 2$ 観測エラーの発見精度}

全観測エラーを含むデータセット $D_{\text {all }}$ を対象とし, 各 方式の予測性能の評価を行った. 10 分割サブセットにお ける結果の平均を表 5 に示す. 適合率, 再現率, F1 score において太字で書かれた箇所は, 信頼度 $95 \%$ 検定にお いて 2 位以下の方式と有意差があるとされた方式を示し 
表 5 実験結果（全観測エラー）

\begin{tabular}{l|r|r|r|r||r|r||r}
\hline 方式 & TP & FN & TN & FP & 適合率 & 再現率 & F1 score \\
\hline Real-time QC $(\mathrm{RQC})$ & $10,195.7$ & 9215.9 & 125471.0 & 685.9 & 0.936 & 0.524 & 0.671 \\
\hline $\mathrm{CRF}\left(\right.$ 手動設計素性関数 $\left.S_{M D}\right)[\mathrm{Ono} 15]\left(\mathrm{CRF}_{\mathrm{MD}}\right)$ & 349.8 & 19061.8 & 126030.6 & 126.2 & 0.736 & 0.018 & 0.035 \\
\hline $\mathrm{CRF}\left(\right.$ 自動設計素性関数 $\left.S_{D T}\right)\left(\mathrm{CRF}_{\mathrm{DT}}\right)$ & 19027.5 & 384.1 & 125544.7 & 612.1 & $\mathbf{0 . 9 7 1}$ & 0.980 & 0.975 \\
\hline $\mathrm{CRF}\left(S_{M D+D T}\right) \quad\left(\mathrm{CRF}_{\mathrm{MD}+\mathrm{DT}}\right)$ & 19061.2 & 350.4 & 125544.7 & 612.1 & $\mathbf{0 . 9 7 1}$ & 0.982 & 0.976 \\
\hline 提案方式 $\left(\mathrm{CRF}_{\mathrm{MD}}+\mathrm{CRF}_{\mathrm{DT}}\right)$ & 19319.4 & 92.2 & 125423.6 & 733.2 & 0.965 & $\mathbf{0 . 9 9 5}$ & $\mathbf{0 . 9 8 0}$ \\
\hline
\end{tabular}

注: 太字の箇所は，該当する指標において，該当する手法と 2 位以下の方式との間に，信頼度 $95 \%$ 検定で有意差がある箇所を示す.

表 6 実験結果（密度逆転，同值エラー，外れ值のみ）

\begin{tabular}{l|r|r|r|r||r|r||r}
\hline 方式 & TP & FN & TN & FP & 適合率 & 再現率 & F1 score \\
\hline Real-time QC $(\mathrm{RQC})$ & 153.1 & 130.8 & 35541.5 & 292.3 & 0.370 & 0.538 & 0.430 \\
\hline $\mathrm{CRF}\left(\right.$ 手動設計素性関数 $\left.S_{M D}\right)[\mathrm{Ono} 15]\left(\mathrm{CRF}_{\mathrm{MD}}\right)$ & 254.6 & 29.3 & 35802.3 & 31.5 & $\mathbf{0 . 8 8 8}$ & 0.897 & $\mathbf{0 . 8 9 2}$ \\
\hline $\mathrm{CRF}$ (自動設計素性関数 $\left.S_{D T}\right)\left(\mathrm{CRF}_{\mathrm{DT}}\right)$ & 34.7 & 249.2 & 35681.9 & 151.9 & 0.573 & 0.120 & 0.147 \\
\hline $\mathrm{CRF}\left(S_{M D+D T}\right)\left(\mathrm{CRF}_{\mathrm{MD}+\mathrm{DT}}\right)$ & 35.6 & 248.3 & 35681.9 & 151.9 & 0.581 & 0.123 & 0.152 \\
\hline 提案方式 $\left(\mathrm{CRF}_{\mathrm{MD}}+\mathrm{CRF}_{\mathrm{DT}}\right)$ & 265.5 & 18.4 & 35652.0 & 181.8 & 0.745 & $\mathbf{0 . 9 3 6}$ & \\
\hline
\end{tabular}

注: 太字の箇所は，該当する指標において，該当する手法と 2 位以下の方式との間に，信頼度 $95 \%$ 検定で有意差がある箇所を示す.

ている. 表より, $D_{\text {all }}$ では, 自動設計された素性関数を用 いる $\mathrm{CRF}_{\mathrm{DT}}, \mathrm{CRF}_{\mathrm{MD}+\mathrm{DT}}$, および $\mathrm{CRF}_{\mathrm{MD}}+\mathrm{CRF}_{\mathrm{DT}}$ の性能が高いことがわかる。適合率については $\mathrm{CRF}_{\mathrm{DT}}$ および $\mathrm{CRF}_{\mathrm{MD}+\mathrm{DT}}$ が高く，再現率およびF1 scoreにつ いては提案方式である $\mathrm{CRF}_{\mathrm{MD}}+\mathrm{CRF}_{\mathrm{DT}}$ が高く，いず れも RQC よりも高い性能であることが確認できる。一 方, 手動で設計された素性を用いる $\mathrm{CRF}_{\mathrm{MD}}$ は, 複数層 にわたる観測エラーに対してフラグ 4 を割り当てること ができず，再現率が極めて低い結果となった.

\section{$4 \cdot 3$ 考察 1: 素性関数の特性の違い}

提案方式における素性関数の特性の違いを検証するた めに，観測エラーの種類を限定したデータセットを対象 とした実験を行った，全観測エラーを含むデータセット $D_{\text {all }}$ のうち, 密度逆転, 複数層同值, 範囲外の 3 種類の観 測エラーのみを含む 1,903 プロファイルを $D_{3 e r r}$ とした. $D_{\text {all }}$ を用いた実験と同様に， $D_{3 e r r}$ を用いた実験につい ても評価の際に観測エラーを含まないプロファイルを追加 した。なお，自動設計された素性関数を用いる $\mathrm{CRF}_{\mathrm{DT}}$ ， $\mathrm{CRF}_{\mathrm{MD}+\mathrm{DT}}$, および $\mathrm{CRF}_{\mathrm{MD}}+\mathrm{CRF}_{\mathrm{DT}}$ では，学習は $D_{\text {all }}$ の分割データセットを用いることとし, $\mathrm{CRF}_{\mathrm{MD}}$ は 学習においても $D_{3 e r r}$ を用いることとした.

10 分割サブセットにおける結果の平均を表 6 に示す. 表 より, $D_{3 e r r}$ では, $D_{\text {all }}$ と比較して $\mathrm{CRF}_{\mathrm{DT}}, \mathrm{CRF}_{\mathrm{MD}+\mathrm{DT}}$ の性能が大幅に低下し, $\mathrm{CRF}_{\mathrm{MD}}$ の性能が高いことがわ かる. すなわち, 自動設計された素性関数は, 密度逆転, 複数層同値, および, 外れ值の 3 種類を対象として手動で 設計された素性と比較して，これらの観測エラーの検知 の性能が劣っていることがわかる。これは，上記 3 種類の エラーが 1 層またはごく少ない観測層に生じるエラーで あるため, 多数の層にフラグ 4 が付与される他のエラー と比較して, 決定木学習の際に重要度が低いと判断され ているためである．素性関数の自動設計を行う際に，上 記のような出現頻度および出現層数の双方の意味での観 測エラー間の不均衡性に対処することは，今後の重要な
課題である.

なお，提案方式である $\mathrm{CRF}_{\mathrm{MD}}+\mathrm{CRF}_{\mathrm{DT}}$ は，適合率 は $\mathrm{CRF}_{\mathrm{MD}}$ よりも低下するものの, 再現率は $\mathrm{CRF}_{\mathrm{MD}}$ よ りも改善されていることが確認できる。このことから， 自動設計された素性は, 上記 3 種類の観測エラーのうち, 手動設計された素性が検知できなかったエラーの一部を 検出できることを示している.

\section{4 考察 2: 異常検知に基づく方式との特性の違い}

異常検知技術に基づく観測エラー検出方式（以下，異 常検知方式とする）[林 18] との特性の違いについて検討 を行った。この方式は教師なし学習を行うため，未知の 種類の観測エラーを検知できる点に特徵がある．提案方 式とは用途が異なるために条件を揃えて比較を行うこと は困難であるが，検知可能な観測エラーの種類に着目す ることで両方式の特性の違いの確認を試みた。

文献 [林 18] における評価実験および本論文における実 験の双方において共通して用いられる526 個のプロファ イル（うち観測エラーを含むプロファイルは 104 個）に 着目して検討を行った。 なお，異常検知方式 [林 18] では， 最もよい性能を示した設定，すなわち，空幅を 10 , 浅層 および中層では k-th Nearest Neighbor, 深層では AvgDiff Algorithm[Kou 06] を用いることとし，それぞれにおい て, 空単位での F1 score が最も高くなるように閾値を設 定した。

両方式による観測エラーの検知結果に着目したところ， 以下のような傾向が見られた。異常検知方式は, 深度方 向での線形補間およびスライド空を用いるため, 教師情 報を用いることなく外れ值の検出を行えることを示した. 一方，方式の特性上，微小なパターンの観測エラー（最 深観測層付近における微小な密度逆転, 複数層同值, 観 測深度の異常など）の検知が困難であった。

提案方式は，教師あり学習を行うことで，上記の微小 な密度逆転等も含めて観測エラーの検出に成功していた. 一方で，提案方式は出現頻度の低い観測エラーパターン 

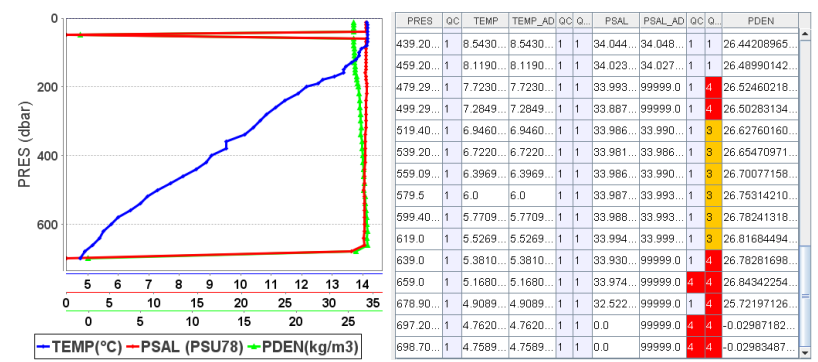

(a) 複数の密度逆転や観測值不良エラーの組み合わせ

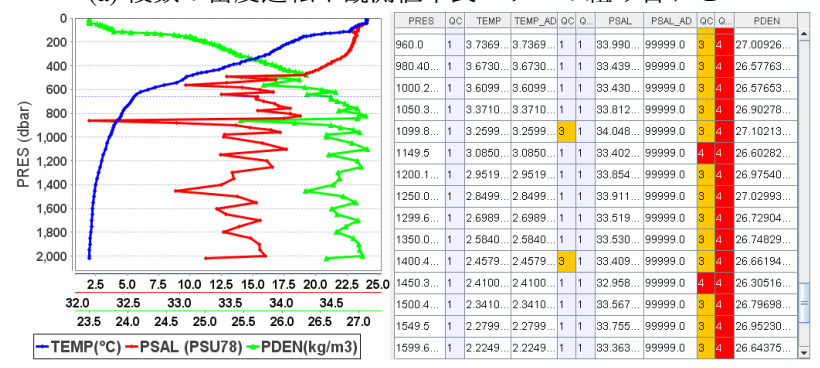

(b) 深度軸方向で比較的連続性のある粗大な凹凸パターン

図 12 提案方式および異常検知方式 [林 18] の双方が検出に失敗し た観測エラーの例

の検出が困難なことがあった。上記 526 プロファイルに は，観測值異常や微小な密度逆転が複数含まれるプロファ イル（図 12(a)）やごく浅い層を除いた広い範囲におい て比較的粗い凹凹状の塩分観測パターンを含むプロファ イル（図 12(b)）*4 など，発生頻度の低い観測エラーの 組み合わせパターンが見られ，提案方式を用いた場合で あっても正確なラベリングが困難であった.

なお，上記 526 プロファイルには，147 件の観測エラー が含まれており， 321 層にフラグ 4 が割り当てられてい た．方式の特性が異なるため公正な比較ではないが，異 常検知は 147 件のうち 85 件を，提案方式は 138 件を検 出することに成功した。

以上のような 2 つ方式の特性の違いを考慮すると, アルゴデータ品質管理の実務において，双方に次のよう な利点が考えられる. 提案方式は運用実績のある機種の フロートについての既知の観測エラーを高いレベルで検 出が可能であり，技術者による目視品質管理の負担軽減 に貢献することが期待される。一方, 異常検知方式 [林 18] は, 現在国際的に活発化している新型フロートやセ ンサの開発により生じる，これまで前例のなかった新た な種類のエラーに対応可能である.このような双方の利 点は，今後長期間にわたり膨大なデータの品質管理を行 う必要があるアルゴ計画にとって, 必要不可欠なツール になることが期待される.

*4 表 1 に示す通り，本実験で対象としたデータセットには，ジ グザクのプロファイルが 63 プロファイルあるが，その多くは より細かく鋭い凹凸の変化パターンを含んでおり，図７に示す ような比較的なだらかで粗い凹凸を含む観測エラーを出力する フロートは極めて少なく，当該分割サブセットの訓練データに は含まれていなかった。

\section{5. おわりに}

海洋観測データの品質向上および均一化を目指して， 観測データを自動検出する方式を提案した。本方式は, 観測エラーパターンの明確さに応じて素性関数を手動お よび自動で設計し，それぞれ個別に利用する 2 つの CRF に基づく識別器を利用する点に特徵がある．実験により， 提案方式は, 現在アルゴプロジェクトで実運用されてい る RQC よりも高い品質で観測エラーの検知を行えるこ とを示し， 2 種類の識別器を併用することで特に再現率 の観点で優れることを示した.

今後, 提案する方式により付与された品質管理フラグ を，RQCで提示される品質管理フラグとは別に，独自の 品質管理フラグとして提供し, DQC の際の専門技術者の 労力の軽減への寄与, および, リアルタイムに提供され るデータに対する信頼度向上に寄与することを目指す.

\section{謝辞}

本研究は独立行政法人海洋研究開発機構 地球環境変 動領域 アルゴデータ班の協力のもとに実施した。また， 本研究の一部は, 科学研究費補助金 (16K12490), 倉田 記念日立科学技術財団 倉田奨励金，および，高橋産業経 済研究財団の支援を受けた。ここに記して感謝の意を表 する.

\section{$\diamond$ 参 考 文 献 $\diamond$}

[Antonov 06] Antonov, J. I., Locarnini, R. A., Boyer, T. P., Mishonov, A. V., and Garcia, H. E.: World Ocean Atlas 2005, Volume 2: Salinity, NOAA Atlas NESDIS 62, U.S. Government Printing Office, Washington, D.C. (2006)

[Argo Data Management Team: Roemmich 01] Argo Data Management Team: Roemmich, D., et al.: Argo: The global array of profiling floats (2001)

[Argo Data Management Team 02] Argo Data Management Team: Report of the Argo Data Management Meeting, in Proc. Argo Data Management Third Meeting, Marine Environmental Data (2002)

[Argo Data Management Team 12] Argo Data Management Team: Argo quality control manual Version 2.7 (2012)

[Carval 12] Carval, T., et al.: Argo data management User's manual, Version 2.4 (2012)

[Hayashi 16] Hayashi, S., Ono, S., Hosoda, S., Numao, M., and Fukui, K.: Error detection of ocean depth series data with area partitioning and using sliding window, in IEEE 15th International Conference on Machine Learning and Applications (ICMLA 2016) (2016)

[林 18] 林 勝悟, 小野智司, 細田 滋毅, 沼尾 正行, 福井健一 : 空間 的自己相関を考慮した海洋データのエラー検知, 人工知能学会論 文誌, Vol. 33, (accepted)

[Hosoda 12] Hosoda, S.: Argo float - Innovation for autonomous observations of global oceans, in 9th Japanese-German Frontiers of Science Symposium, pp. 37-38 (2012)

[細田 13] 細田 滋毅 : 全球海洋監視システム「アルゴ」, 2013 年 度人工知能学会全国大会（第 27 回）, No. 3K1-OS-08a-1 (2013)

[上川路 16a] 上川路洋介, 松山開, 福井健一, 細田 滋毅, 小野 智 司 : 海洋観測データの良否識別を目的とした条件付確率場にお ける素性関数の自動設計の試み, 2016 年度人工知能学会全国大 会（第 30 回）, No. 2K4-OS-25a-3 (2016)

[Kamikawaji 16b] Kamikawaji, Y., Matsuyama, H., Fukui, K., Hosoda, S., and Ono, S.: Decision tree-based feature function de- 
sign in conditional random field applied to error detection of ocean observation data, in 2016 IEEE Symposium Series on Computational Intelligence (IEEE SSCI 2016) (2016)

[Kou 06] Kou, Y., Lu, C.-T., and Chen, D.: Spatial weighted outlier detection, in Proceedings of the 2006 SIAM International Conference on Data Mining, pp. 614-618SIAM (2006)

[Lafferty 01] Lafferty, J. D., McCallum, A., and Pereira, F. C. N.: Conditional random fields: Probabilistic models for segmenting and labeling sequence data, in Proceedings of the Eighteenth International Conference on Machine Learning (ICML'01), pp. 282289, San Francisco, CA, USA (2001), Morgan Kaufmann Publishers Inc.

[Locarnini 16] Locarnini, R. A., Mishonov, A. V., Antonov, J. I., Boyer, T. P., and Garcia, H. E.: World Ocean Atlas 2005 Volume 1: Temperature, NOAA Atlas NESDIS 61, U.S. Government Printing Office, Washington, D.C. (2016)

[松山 14] 松山開, 小野智司, 福井 健一, 細田 滋毅: 機械学習によ る海洋観測データの良否分類に向けた初期検討, 2014 年度人工 知能学会全国大会（第 28 回）オーガナイズドセッション「グ リーン AI 〜 人知能による環境貢献〜」, No. 1B2-OS-02a-3in (2014)

[松山 15] 松山 開, 小野智司, 福井 健一, 細田 滋毅: 機械学習によ るアルゴデータの良否識別, 日本海洋学会春季大会 (2015)

[Olshen 84] Olshen, L., and Stone, C. J., et al.: Classification and regression trees, Wadsworth International Group, Vol. 93, No. 99, p. 101 (1984)

[Ono 15] Ono, S., Matsuyama, H., Fukui, K.-i., and Hosoda, S.: A preliminary study on quality control of oceanic observation data by machine learning methods, in Proceedings of the 18th Asia Pacific Symposium on Intelligent and Evolutionary Systems, Volume 1, pp. 679-693, Springer (2015)

[Seymore 99] Seymore, K., McCallum, A., and Rosenfeld, R.: Learning hidden Markov model structure for information extraction, in AAAI-99 Workshop on Machine Learning for Information Extraction, pp. 37-42 (1999)

[Sutton 12] Sutton, C. and McCallum, A.: An introduction to conditional random fields, Foundations and Trends in Machine Learning, Vol. 4, No. 4, pp. 267-373 (2012)

[Tozuka 07] Tozuka, T, et al.: Decadal modulations of the Indian Ocean dipole in the SINTEX-F1 coupled GCM, Journal of Climate, pp. 2881-2894 (2007)

\section{〔担当委員 : 栗原 聡〕}

2017 年 3 月 31 日 受理

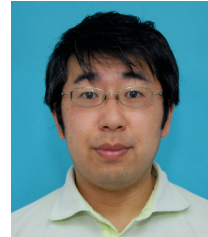

福井 健一(正会員)

2003 年名古屋大学大学院人間情報学研究科物質・生命情報 学専攻博士前期課程修了, 博士（情報科学），2005 年上り 大阪大学産業科学研究所新産業創造物質基盤技術研究セン タ一特任助手, 特任助教を経 $\tau, 2010$ 年大阪大学産業科学 研究所助教. 2015 年より同准教授、機械学習・データマイ ニングによるデータ中心科学と環境貢献に関する研究に興 味を持つ. 本学会 2011 年度全国大会優秀賞（口頭発表部 門），2013，2016 年研究会優秀賞等受賞. IEEE Compute Society, 情報処理学会, 電子情報通信学会, 進化計算学会各会員。

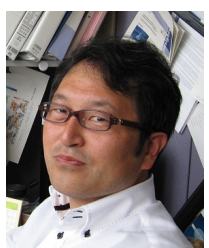

細田 滋毅

2001 年北海道大学大学院地球環境科学研究科大気海洋科 学専攻博士後期課程修了。博士 (地球環境).2001 年より 海洋科学技術センター（現国立研究開発法人海洋研究開発 機構）海洋観測研究部研究員, 2011 年同地球環境変動研 究センター・戦略的海洋監視研究チーム・チームリーダー 代理, 2014 年より同地球環境観測研究開発センター・海洋 循環研究グループ・グループリーダー代理，地球規模の気 候変動に伴う海洋環境・循環の変動とそのメカニズムにつ いて，主として自動卓降型漂流ブィ（アルゴフロート）等の観測データを用いた 研究に従事，同機構における国際アルゴ計画の実施・フロート展開を担当。米国 地球物理学連合, 日本海洋学会, 気像学会各会員.

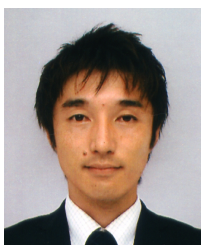

小野 智司(正会員)

2002 年筑波大学大学院工学研究科博士課程修了. 2001 年 日本学術振興会特別研究員. 2003 年鹿児島大学工学部情 報工学科助手. 2010 年同大学院理工学研究科情報生体シ ステム工学専攻准教授，現在に至る. 博士 (工学). 進化 計算とその応用の研究に従事. 2009 年, 2016 年本学会 研究会優秀賞，2010 年度本学会全国大会優秀賞，芸術科 学会論文誌論文賞, 2013 年 情報処理学会山下記念研究賞, 2015 年情報処理学会シンポジウムインタラクション 2015 ベストペーパー賞等受賞．IEEE，情報処理学会，電子情報通信学会，進化計算学 会等各会員.

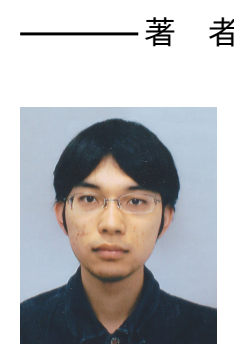

\section{者 紹 介}

\section{上川路 洋介}

2016 年 3 月 鹿児島大学工学部情報生体システム工学科卒 業. 在学中は, 機械学習とその海洋観測データの品質管理 への応用の研究に従事.

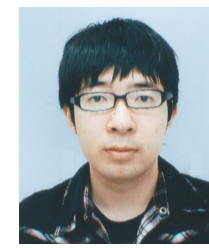

\section{松山開}

2013 年 3 月 鹿児島大学工学部情報生体システム工学科 卒業. 2015 年 3 月鹿児島大学大学院理工学研究科情報 生体システム工学専攻. 在学中は, 機械学習とその海洋観 測データの品質管理への応用, 量子アルゴリズムの研究に 従事. 